\title{
Reference:
}

Aleixo, A.; Azeiteiro, U.; \& Leal, S. (2020). Are the Sustainable Development Goals being implemented in the Portuguese Higher Education Formative Offer? International Journal of Sustainability in Higher Education, 21(2). https://doi.org/10.1108/IJSHE-04$\underline{2019-0150}$

\section{Are the sustainable development goals being implemented in the Portuguese higher education formative offer?}

\author{
Ana Marta Aleixo and Ulisses M. Azeiteiro \\ Department of Biology and Centre for Environmental and Marine Studies, \\ University of Aveiro, Aveiro, Portugal, and \\ Susana Leal \\ School of Management and Technology of Santarem, \\ Polytechnic Institute of Santarém, Santarém, Portugal and \\ Life Quality Research Centre, Santarém, Portugal
}

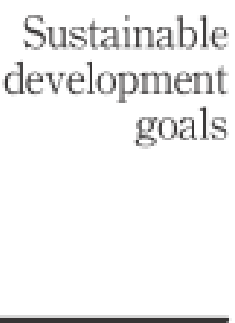

Received 15 April 2019 Revised 12 Alugust 2019 3 Nowember 2019 6 bmary 2000 Acoepted 6 January 200 )

\begin{abstract}
Purpose - The study aims to examine the vertical integration of the sustainable development goals (SGDs) in Portuguese public higher education institutions, namely, at the level of undergraduate and master's degrees, and the extent to which Portuguese higher education institutions (HEI) are preparing for the United Nations' call to promote SDGs.

Design/methodology/approach - A content analysis of the designations and objectives of the 2,556 undergraduate and master's degrees (in 33 Portuguese public higher education institutions) was done to determine whether they promote at least one SDG.

Findings - The results show that 198 courses directly address at least one SDG; on average, each higher education institution (HED) has six courses that explicitly address at least one SDG; universities have more courses in SDG areas than in polytechnics more master's degrees embrace SDGs than undergraduate degrees: and most of the courses addressing SDGs are from the social sciences and humanities areas and from natural and environmental sciences.

Originality/value - This paper serves to raise the awareness of Portuguese HEIs of their role and responsibility in furthering SGDs,

Keywords Education for sustainable development, Higher education, Sustainable development goals, Sustainability curriculum, Portuguese higher education

Paper type Research paper

Acronyms

DESD = Decade of education for sustainable development;

ESD = Education for sustainable development;

GUPES = Global Universities' Partnership on Environment and Sustainability;

HEI = Higher education institution;

HESD = Higher education for sustainable Development;
\end{abstract}

The authors are grateful to the four reviewers for their helpful oomments and reoommendations,

This work had financial support of Fundaçấo para a Ciência e Tecnologia Centre (Grant UID) CED/04748/2019). 


\title{
Are the Sustainable Development Goals being implemented in the Portuguese Higher Education Formative Offer?
}

\author{
Ana Marta Aleixo \\ Department of Biology \& Centre for Environmental and Marine Studies, University of Aveiro, \\ Campus Universitário de Santiago, 3810-193 Aveiro, Portugal \\ and \\ Polytechnic Institute of Leiria, Rua General Norton de Matos - Apartado 4133 - 2411-901 Leiria, \\ Portugal \\ marta.aleixo@ua.pt
}

Ulisses Azeiteiro

Department of Biology \& Centre for Environmental and Marine Studies, University of Aveiro, Portugal

ulisses@ua.pt

\begin{abstract}
Susana Leal
School of Management and Technology of Santarém \& Life Quality Research Centre, Polytechnic Institute of Santarem, Portugal
\end{abstract}

Susana.leal@esg.ipsantarem.pt

\begin{abstract}
Purpose. The study aims to examine: (a) the vertical integration of the Sustainable Development Goals (SGDs) in Portuguese public higher education institutions, namely at the level of undergraduate and master's degrees, and (b) the extent to which Portuguese higher education institutions are preparing for the United Nations call to promote SDGs.

Method. A content analysis of the designations and objectives of the 2556 undergraduate and master's degrees (in 33 Portuguese public higher education institutions) was made to determine whether they promote at least one sustainable development goal.

Findings. The results show that: (a) 198 courses directly address at least one SDG; (b) on average, each higher education institution (HEI) has 6 courses that explicitly address at least one SDG; (c) universities have more courses in SDG areas than polytechnics; (d) more master's degrees
\end{abstract}


embrace SDGs than undergraduate degrees; and (e) most of the courses addressing SDGs are from the social sciences and humanities areas and from natural and environmental sciences.

Value. This paper serves to raise the awareness of Portuguese higher education institutions of their role and responsibility in furthering sustainable development goals.

\section{Acknowledgments}

The authors are very grateful to the four reviewers for their helpful comments and recommendations.

This work had financial support of Fundação para a Ciência e Tecnologia Centre (Grant UID/CED/04748/2019).

\section{Declarations of interest}

None

\section{Acronyms}

DESD - Decade of Education for Sustainable Development

ESD - Education for Sustainable Development

GUPES - Global Universities' Partnership on Environment and Sustainability

HEI - Higher Education Institution

HESD - Higher Education for Sustainable Development

MDGs - Millennium Development Goals

SD - Sustainable Development

SDGs - Sustainable Development Goals

SHE - Sustainable and Higher Education

SHEls - Sustainable Higher Education Institutions

UN SDGs - United Nations Sustainable Development Goals

UN- United Nations

UN-DESD - United Nations Decade of Education for Sustainable Development

URSD - University research for sustainability development

Keywords: Education for Sustainable Development; Higher Education; Sustainability Curriculum; Sustainable Development Goals, Portuguese Higher Education 


\section{Introduction}

The $57^{\text {th }}$ session of the United Nations General Assembly in December 2002 adopted Resolution 57/254 announcing the United Nations Decade of Education for Sustainable Development (UNDESD) for the period between 2005 and 2014. This resolution aimed to highlight education's critical role in bringing about a more sustainable world (Wals, 2014).

In light of the new UN-DESD (2014-2025), it is time to identify the extent to which Higher Education Institutions (HEI) have introduced Sustainable Development (SD) in all their activities through a "top down" process, starting with planned activities from the governing body and then involving all stakeholders. To this end, SDGs are included in the 2030 Agenda for Sustainable Development (SD), launched in September 2015, aimed at promoting the acquisition of knowledge and skills for SD. The agenda is an action plan for SD. Leal Filho et al. (2017a) noted that the Sustainable Development Goals could provide an opportunity to overcome the barriers to achieving sustainability in HEls.

Although the study by Aleixo et al. (2018a) suggests that HEls and society recognize the great importance of SD, it has not yet been fully integrated into the HEl system and activities. For Ramos et al. (2015), the development of Higher Education for Sustainable Development (HESD) entails a more effective inclusion of Education for Sustainable Development (ESD) in courses. And despite documented case studies in recent years on changes in HEl curricula, ESD is still not practiced in most HEls and remains a great challenge (Barth and Rieckmann, 2012). Moreover, although SDG4, target 4.7 , specifically mentions the acquisition of knowledge and skills by all learners to promote SD, it is not known whether the Higher Education formative offer has adapted to achieve this objective. The focus of this paper is therefore to understand how ESD is implemented in Portuguese HEIs, namely through the offer of undergraduate and master degree courses.

This study addresses the 17 SDGs and aims to investigate whether the graduate and postgraduate offer in Portugal's public HEls is aligned with SDGs. In view of the above, it aims to examine: (a) the vertical integration of Sustainable Development Goals in Portuguese public higher educations, namely in undergraduate and master's degrees, and (b) the extent to which Portuguese higher education institutions are prepared for the United Nations call to promote SDGs. 


\section{Literature review}

The 2030 Agenda for Sustainable Development

UNESCO (2014) has reiterated that it is important that "citizens are equipped with the knowledge, skills and values to make choices that will support living and working sustainably. Education can - and must - play a decisive role in the journey towards sustainable development" (p.39). Advances in education at all levels and in all areas is a critical tool to move societies towards sustainability. According to UNESCO (2014), the Global Monitoring and Evaluation Final Report shows progress is being made; in particular, it states that "Education for Sustainable Development is achieved by raising awareness, influencing policies and generating significant numbers of good practice projects in all areas and levels of education and learning" (p.202). Wals (2014) also pointed out that HEls were starting to make systemic changes to foster sustainability through reorientation in education, research, operations and community outreach activities.

The SDGs are a framework of 17 goals (Table 1 ) and 169 targets across social, economic and environmental areas of SD. The United Nations Member States have made a commitment to reach these goals in the coming years in all countries (until 2030). The SDGs are part of the 2030 Agenda for SD adopted at the United Nation Sustainable Development Summit in September 2015 and which came into force in January 2016. The outcome document of the process, entitled "Transforming Our World: The 2030 Agenda for Sustainable Development", which compiled these objectives, sets out ways to implement, monitor and review.

Table 1 -SDG Goals

\begin{tabular}{|l|l|}
\hline SDG designation & SDG meaning \\
\hline SDG 1 - No poverty & End poverty in all its forms \\
\hline SDG 2 - Zero hunger & $\begin{array}{l}\text { End hunger, achieve food security and improved nutrition and } \\
\text { promote sustainable agriculture }\end{array}$ \\
\hline SDG 3 - Good health and well-being & Ensure healthy lives and promote well-being for all at all ages \\
\hline SDG 4- Quality education & $\begin{array}{l}\text { Ensure inclusive and equitable quality education and promote } \\
\text { lifelong learning opportunities for all }\end{array}$ \\
\hline SDG 5-Gender equality & Achieve gender equality and empower all women and girls \\
\hline SDG 6-Clean water and sanitation & $\begin{array}{l}\text { Ensure availability and sustainable management of water and } \\
\text { sanitation for all }\end{array}$ \\
\hline SDG 7 - Affordable and clean energy & $\begin{array}{l}\text { Ensure access to affordable, reliable, sustainable and modern } \\
\text { energy for all }\end{array}$ \\
\hline SDG 8 - Decent work and economic growth & $\begin{array}{l}\text { Promote sustained, inclusive and sustainable economic growth, } \\
\text { full and productive employment and decent work for all }\end{array}$ \\
\hline
\end{tabular}




\begin{tabular}{|c|c|}
\hline $\begin{array}{l}\text { SDG } 9-\text { Industry, innovation and } \\
\text { infrastructures }\end{array}$ & $\begin{array}{l}\text { Build resilient infrastructures, promote sustainable } \\
\text { industrialization and foster innovation; }\end{array}$ \\
\hline SDG 10 - Reduce inequalities & Reduce inequality within and among countries \\
\hline SDG 11 - Sustainable cities and communities & Make cities inclusive, safe, resilient and sustainable \\
\hline $\begin{array}{l}\text { SDG } 12-\text { Responsible consumption and } \\
\text { production }\end{array}$ & Ensure sustainable consumption and production patterns \\
\hline SDG 13 - Climate action & Take urgent action to combat climate change and its impacts \\
\hline SDG 14 - Life below water & $\begin{array}{l}\text { Conserve and sustainably use the oceans, seas and marine } \\
\text { resources }\end{array}$ \\
\hline SDG 15 - Life on land & $\begin{array}{l}\text { Sustainably manage forests, combat desertification, halt and } \\
\text { reverse land degradation, halt biodiversity loss }\end{array}$ \\
\hline $\begin{array}{l}\text { SDG } 16-\text { Peace, justice and strong } \\
\text { institutions }\end{array}$ & $\begin{array}{l}\text { Promote peaceful and inclusive societies for SD, provide access to } \\
\text { justice for all and build effective, accountable and inclusive } \\
\text { institutions at all levels }\end{array}$ \\
\hline SDG 17 - Partnerships for the goals & Revitalize the global partnership for SD \\
\hline
\end{tabular}

Source: Elaborated by the authors with public information from United Nations (2015)

Elder et al. (2016) argue that sufficient means must be made available to implement these goals. According to Hajer et al. (2015), SGDs need to mobilize new and multiple agents of change. It is only possible to reach these goals if all parties are involved and are committed to taking responsibility for action. Hence, it should be stressed that "the SGDs have the potential to become the guiding vision for governmental, corporate and civil society action for a shared and lasting prosperity" (Hajer et al., 2015). The implementation will rely on countries and their different tools (SD policies, plans and programs).

As education is essential to SD, it is the subject of a specific goal (objective 4) which highlights the importance of HEI. Education is both a goal in itself and also a means to reach all other goals (United Nations, 2015).

The increasing involvement of HESD is well known, notably in response to 4.7 of the SDGs. This goal aims to ensure that, by 2030 , all students acquire the knowledge and skills necessary to promote SD, including, inter alia, through ESD and sustainable lifestyles, human rights, gender equality, promotion of a culture of peace and non-violence, global citizenship and cultural diversity and the contribution of culture to SD (United Nations, 2015).

Many authors argue that HEls have the moral obligation and responsibility to ensure their graduates develop the right vision to promote quality of life for future generations (Segalàs et al., 2010). Nonetheless, traditional education has not offered graduates training to develop solutions to the emerging world problems (Sibbel, 2009) and it was recognized that "sustainability is seldom systematically embedded in the curriculum"; this constitutes a major 
barrier to the incorporation of SD in HEI (Leal Filho, 2018). In light of this responsibility and barrier, it is imperative that all HE courses gradually and systematically address SDGs.

The HEls should embrace ESD and have curricular units that develop relevant competences in graduates (Wiek et al., 2011, Wiek, 2015, Thomas, 2016, Leicht et al., 2018). Segalàs et al. (2010) believe that the increase in students' knowledge of $S D$ is found primarily in community-oriented courses with a more constructive, active learning pedagogy, namely through methodologies such as: (i) lecturing, (ii) project-based learning, (iii) case study, (iv) problem-based learning, (v) backcasting and (vi) role play.

For Sibbel (2009), "Higher Education must develop the capacity in graduates to prioritise actions after balancing all the social, environmental and economic cost and benefits" ( $p$. 79). Students' sustainability competencies can be developed by fostering their ability to be active and critical citizens, "able to participle in shaping a sustainable future" (Leicht et al., 2018). For Wiek et al. (2011, 2015), five competencies should be developed in students to promote sustainability, namely: (i) systems thinking; (ii) futures thinking (or anticipatory); (iii) values thinking (or normative); (iv) strategic thinking (or action-oriented); (v) collaboration (or interpersonal). Wiek (2015) claims there are few examples of the objective introduction of these competencies in the different levels of education, namely as specific learning goals (e.g., Arizona State University). Leal Filho et al. (2019) recommends HEls to test and use new contents, learning methods and transformative approaches.

Although the policies aimed at reforming curricula to include sustainability have been successful (Radford, 2012), Popescu and Beleau (2014) draw attention to the lack of indicators to measure the integration of SD issues in curricula.

Education for Sustainable Development (EDS) can be integrated in higher education: (i) vertically and (ii) horizontally. The former integrates sustainability though specific sustainability-related courses while the latter includes sustainability within the regular courses in the study plan (Figueiró and Raufflet, 2015, Stough et al., 2017). An "Environment and Sustainability Studies" master course is an example of the vertical introduction of sustainability into HEI; on the other hand, the horizontal integration of ESD is achieved through interweaving sustainability in different courses of the curriculum (Figueiró and Raufflet, 2015). However, ESD can also be introduced through different pedagogical approaches, like: (i) a learner-centered approach; (ii) action-oriented learning and (iii) transformative learning (Leicht et al., 2018). Barth and Rieckmann (2012) argue that changes in the curriculum can successfully foster SD by taking four main aspects into account: (i) linking theory and practice; (ii) interdisciplinary co-operation; (iii) 
informal learning and (iv) leadership approaches. To quote Barth and Rieckmann (2012) "sustainable development is not just another topic to be considered in the curriculum, but challenges traditional discipline-oriented and teacher-centered teaching and asks for participatory and competence-oriented approaches in higher education" (p.15).

According to Lozano (Lozano et al., 2015), the main examples presented to implement ESD in HEls are: offering students the possibility to take classes in another faculty; integrating SD courses in programs; offering optional SD courses; inviting SD guest lecturers; promoting systems and holistic thinking in teaching activities; providing continuous education to external stakeholders; fostering the link between the natural sciences and the social sciences; providing SD education to educators and integrating SD in all programs, courses and faculties. Some examples of the implementation of ESD can be found in Leal Filho et al. (2017b) and in Leal Filho (2018).

\section{The Portuguese Scenario}

According to Lozano et al. (2015), despite considerable SD implementation (Lozano et al., 2015), "in general, the implementation of SD in HEls has been compartmentalized and not holistically integrated throughout the institutions" (p.14). In Portugal, HEls do not yet prioritize implementing SD throughout the system and this must therefore be addressed (Aleixo et al., 2018b). Previous studies show a lack of national integrated strategies and policies, plans and programs on the integration of ESD into Portuguese HEI (Farinha et al., 2017) as well as an absence of a centralized system for implementing sustainable in HEls (Farinha et al., 2018). Despite the lack of both government institutions' commitment to implement ESD in higher education and documents linked to SD, "Portuguese universities' autonomy and their social responsibility have led them to develop several initiatives and policies toward ESD" (Farinha et al., 2018). Portugal has recently published a Green Paper on Social Responsibility and Higher Education Institutions (ORSIES - Observatório da Responsabilidade Social e Instituições de Ensino Superior, 2018) with the support of the State Secretariat for Science, Technology and Higher Education. This document places SDGs at the center of HEl practices, namely in the formative offer domain and therefore signals the recent change in Portuguese Public Policies to promote the ESD. Nowadays, there is debate on how SD should be assessed and reported by HEls.

According to the Final Report of the UN Decade of Education for Sustainable Development (UNESCO, 2014), the Global Universities Partnership on Environment and Sustainability (GUPES) aims to introduce environmental and sustainability practices into the curricula and supports 
over 10 annual sustainability training programs involving 300 universities. After consultation, it was found that twenty-two Spanish HEls are involved in this consortium but no Portuguese HEls (GUPES, 2016). This lack of involvement of Portugal's HEIs in the network is indicative of the scarcity of Portuguese Public Policies to promote ESD. Despite the insufficient national combined strategies or policies related to ESD, the results of Farinha et al. (2019) show that the SD "movement has made progress at the university level, with good examples and initiatives in several Portuguese universities" (p. 20). Nevertheless, Farinha et al. (2019) only identified three HEI (from a list of 14) that introduced sustainability through courses or programs on SD (4 courses in total; Farinha et al., 2019, p. 11).

Recent studies in Portugal (e.g., Aleixo et al., 2018a) showed that although Portuguese HEls recognize the need to introduce sustainable competencies and topics in all courses, their vision of how to implement this differs. While stakeholders defend that research and dissemination of SD knowledge should be encouraged and transversal to all HEls, the study by Aleixo et al. (2018b) shows there is no HEl strategy for education or the information society for sustainability. There is an urgent need for a conceptual and organizational change in HEls towards a sustainable HEI (Aleixo et al., 2018b), including strategic planning for the formal and informal integration of courses promoting ESD. Aleixo et al. (2018b) notes that some interviewees mention the need to introduce sustainability as a topic in the curriculum to further the role of HESD. According to Aleixo et al. (2018a), HEls need to be aware that they can empower students with skills to address society's problems for future wellbeing by encompassing sustainability in all their activities and, particularly in education.

The Portuguese higher education system is characterized by a binary system of universities and polytechnics. Despite common objectives, the two types of HEI have particularities defined by law. Indeed, the basic law of the education system (Lei n. 46/86 - Lei de Bases do Sistema Educativo [Law No. 46/86 - Basic Law of the Educational System], Diário da República n.o 237/1986) characterizes university education as "guided by a constant perspective of promoting research and the creation of knowledge, [which] aims to ensure a sound scientific and cultural preparation and to provide technical training that enables the exercise of professional and cultural activities and fosters the development of capacities of conception, innovation and critical analysis" (11rd article, no 3); on the other hand, polytechnic education is "guided by a constant perspective of applied research and development, aimed at understanding and solving concrete problems, aimed to provide a solid cultural and technical education at a higher level, develop the capacity for innovation and critical analysis and provide scientific knowledge of a theoretical and practical nature and its applications for the pursuit of professional activities" 
(11rd article, no 4). Moreover, while qualifications for some professional activities e.g. law and medicine, can only be obtained at universities, polytechnics also have professional courses that are not offered in universities.

Relative to the 2030 Agenda for SD, the Portuguese government made a public commitment in July 2017 to SDG 4, 5, 9, 10, 13 and 14 (Ministry of Foreign Affairs, 2017). Quality education, gender equality, industry, innovation and infrastructures, reducing inequalities, climate action and protecting marine life are strategic areas for Portugal.

In light of the above, the study proceeds with the analysis of the vertical integration of SD (Figueiró and Raufflet, 2015) in the HEl formative offer, namely in the undergraduate and master's courses in Portugal.

\section{Method}

The implementation of SDGs in all undergraduate and master's courses in Portuguese public HEls (polytechnics and universities) is measured by means of a content analysis of the course designations and objectives. The information was accessed on the HEls websites. The study examined the undergraduate and master's courses of the 33 Portuguese public HEls, 19 of which are polytechnics and 14 universities. All the 957 undergraduate and 1599 master's courses in the websites were listed and the course designations and objectives analysed.

The content analysis method has been successfully advocated in the literature reviewed (Lozano, 2010, Brondani et al., 2014, Katiliūtè et al., 2014, Amaral et al., 2015). This method (Krippendorff, 2013, Bardin, 2014) consists of classifying the information disclosed in different categories that represent the different SDGs. A system code for the classification of SDG was developed from the list of SDGs and targets. This system code has a list of categories for each SDG. Then each course was analysed by means of the presence/absence of criteria in each SDG (if, at least, one category is present in the courses' designations and objectives, then there is evidence that the course is related with the respective SDG). That is, for each course and SDG, a point was assigned whenever in the course designation and objectives there is at least one mention to the words listed in the system code (i.e., 0 : there is no evidence of the respective SDG on the course; 1 : there is evidence of the SDG on the course). The scores were not weighted as it is assumed each SDG is equally important. This process is illustrated in Figure 1. This code was then adapted as necessary when analyzing the course designations and objectives. Note 
that the classification system considered a course as being aligned with the SDG when it explicitly addresses SDG topics (identified in the inclusion criteria).

Figure 1 - Diagram of the analysis process

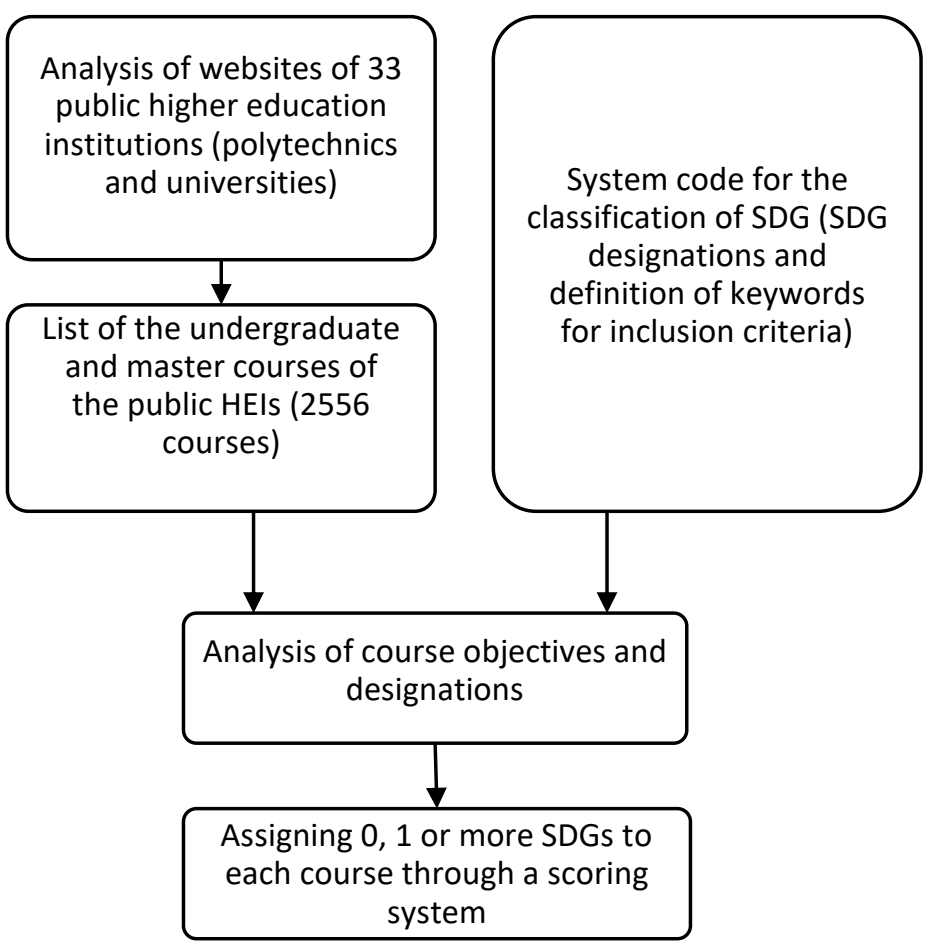

For example, in the case of SDG 15 (Life on land) the categories considered in the system code comprehend the following list of words and sentences: biodiversity, biodiversity conservation, combat desertification, ecosystem, ecosystem services, extinction, forestation, landscape ecology, habitat fragmentation, soil degradation, sustainable forest management and sustainable agriculture. Then, when the courses with the designation of "Sustainable Agriculture" were analysed, a point was assigned in the SDG15. For courses that their designation does not permit a direct classification on the SDGs, then the content of the courses' objectives was analysed. For example, the "Environmental Engineering" courses mention, in their objectives, topics related with landscape ecology and management of ecosystems, and, then, these courses have a point assigned in the SDG15.

Where applicable, one course could receive one point in more than an SDG. It is the case of the "Environmental and Sustainability Studies" course that was assigned to two SDGs: SDG 7 (Affordable and clean energy) and SDG13 (Climate action).

The data was collected from 1 December 2017 until March 2018 (2017/2018 school year) and each of the $33 \mathrm{HEl}$ website was manually reviewed. The accuracy of coding was ensured by a systematic procedure. To avoid bias in the interpretation, three researchers from different 
training areas reviewed each program at least four times and analyzed the results independently. At the end of the process, the courses with different classifications in each SDG were revised in a meeting were the three researchers shared their interpretation of the classification and, then, a decision about the SDG associated to each course was made by consensus.

The sample is composed of 2556 Portuguese HEI, of which: (i) 944 are from polytechnic institutions and 1612 from universities, (ii) 957 are undergraduate degrees and 1599 are master's degrees. Table 1 below shows in detail the sample by type of institution and academic degree. The courses were offered by $33 \mathrm{HEls}$ (19 polytechnics and 14 universities).

Table 2 - Sample of courses identified

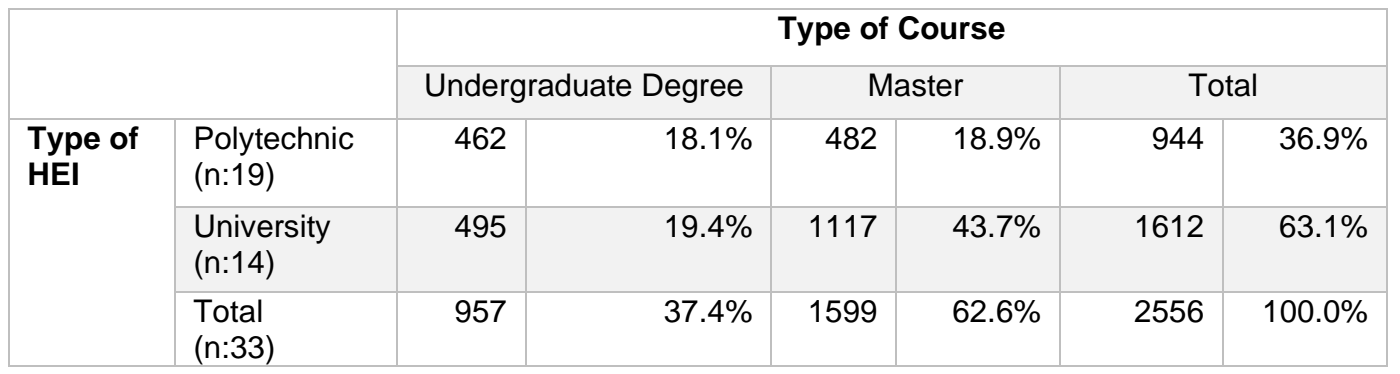

The data were analyzed through descriptive statistics techniques (e.g., absolute frequencies, contingency tables). Fisher's nonparametric exact test (Fisher, 1925) was performed to determine whether there was a significant difference in the number of courses addressing SDGs in polytechnics and universities. The same procedure was used to determine the difference in the number of courses addressing SDGs in undergraduate and master's degrees.

\section{Results}

This analysis confirmed that 198 courses respond to at least one SDG. Most courses address only one SDG ( $n: 136), 49$ courses address two SDGs, ten courses address three SDGs and one addresses four SDGs. The following SDGs were represented in the largest number of courses in different institutions (Table 3): SDG 15 - life on land (n: 37), SDG 7 - affordable and clean energy ( $n: 36)$ and SDG 6 - clean water and sanitation (n: 25). The least represented SDGs are: SDG 1 no poverty, and 17 - partnerships for the goals. It should be noted that $7.7 \%$ of courses addressed at least one SDG, and each HEI has on average 6 courses (198 courses in $33 \mathrm{HEI}$ ) that are explicitly related with SDGs.

Table 3 - Number of courses per SDG, by type of institution and type of degree 


\begin{tabular}{|c|c|c|c|c|c|c|c|}
\hline \multirow[b]{2}{*}{ SDG } & \multirow[b]{2}{*}{ All HEI } & \multicolumn{3}{|c|}{ Type of institution } & \multicolumn{3}{|c|}{ Type of degree } \\
\hline & & Polytechnic & University & $\begin{array}{l}\text { Fisher's } \\
\text { Exact Test a }\end{array}$ & $\begin{array}{l}\text { Undergraduate } \\
\text { Degree }\end{array}$ & Master & $\begin{array}{c}\text { Fisher's } \\
\text { Exact Test }{ }^{b}\end{array}$ \\
\hline $\begin{array}{l}\text { At least one SDG's } \\
\text { is addressed in the } \\
\text { course }\end{array}$ & 198 & 81 & 117 & 0.250 & 40 & 158 & 0.000 \\
\hline SDG1 - No poverty & 0 & 0 & 0 & n.a. & 0 & 0 & n.a. \\
\hline $\begin{array}{l}\text { SDG2 - Zero } \\
\text { hunger }\end{array}$ & 7 & 7 & 0 & 0.001 & 2 & 5 & 1.000 \\
\hline $\begin{array}{l}\text { SDG3 - Good } \\
\text { health and well- } \\
\text { being }\end{array}$ & 25 & 12 & 13 & 0.298 & 3 & 22 & 0.007 \\
\hline $\begin{array}{l}\text { SDG4 - Quality } \\
\text { education }\end{array}$ & 22 & 13 & 9 & 0.044 & 3 & 19 & 0.025 \\
\hline $\begin{array}{l}\text { SDG5 - Gender } \\
\text { equality }\end{array}$ & 3 & 0 & 3 & 0.301 & 0 & 3 & 0.297 \\
\hline $\begin{array}{l}\text { SDG6 - Clean } \\
\text { water and } \\
\text { sanitation }\end{array}$ & 25 & 7 & 18 & 0.410 & 9 & 16 & 1.000 \\
\hline $\begin{array}{l}\text { SDG7 - Affordable } \\
\text { and clean energy }\end{array}$ & 36 & 14 & 22 & 0.862 & 13 & 23 & 1.000 \\
\hline $\begin{array}{l}\text { SDG8 - Decent } \\
\text { work and economic } \\
\text { growth }\end{array}$ & 16 & 12 & 4 & 0.003 & 0 & 16 & 0.001 \\
\hline $\begin{array}{l}\text { SDG9 - Industry, } \\
\text { innovation and } \\
\text { infrastructures }\end{array}$ & 13 & 6 & 7 & 0.568 & 2 & 11 & 0.149 \\
\hline $\begin{array}{l}\text { SDG10 - Reduce } \\
\text { inequalities }\end{array}$ & 14 & 3 & 11 & 0.278 & 0 & 14 & 0.002 \\
\hline $\begin{array}{l}\text { SDG11 - } \\
\text { Sustainable cities } \\
\text { and communities }\end{array}$ & 10 & 1 & 9 & 0.103 & 1 & 9 & 0.102 \\
\hline $\begin{array}{l}\text { SDG12-- } \\
\text { Responsible } \\
\text { consumption and } \\
\text { production }\end{array}$ & 13 & 5 & 8 & 1.000 & 1 & 12 & 0.040 \\
\hline $\begin{array}{l}\text { SDG13 - Climate } \\
\text { action }\end{array}$ & 16 & 3 & 13 & 0.193 & 6 & 10 & 1.000 \\
\hline $\begin{array}{l}\text { SDG14 - Life } \\
\text { below water }\end{array}$ & 19 & 5 & 14 & 0.475 & 7 & 12 & 1.000 \\
\hline $\begin{array}{l}\text { SDG15 - Life on } \\
\text { land }\end{array}$ & 37 & 15 & 22 & 0.732 & 11 & 26 & 0.394 \\
\hline $\begin{array}{l}\text { SDG16 - Peace, } \\
\text { justice and strong } \\
\text { institutions }\end{array}$ & 12 & 0 & 12 & 0.005 & 0 & 12 & 0.005 \\
\hline $\begin{array}{l}\text { SDG17 - } \\
\text { Partnerships for the } \\
\text { goals }\end{array}$ & 0 & 0 & 0 & n.a. & 0 & 0 & n.a. \\
\hline
\end{tabular}

Notes: a Fisher's exact test to compare the number of courses with SDG in polytechnics versus universities (Exact Sig. 2-sided). ${ }^{b}$ Fisher's exact test to compare the number of courses with SDG in undergraduate degrees versus master degrees (Exact Sig. 2-sided). n.a. not applicable

With regard to the differences between institutions (Table 3), it was found that 81 polytechnic vis-a-vis 117 university courses address at least one SDG. In polytechnics, the following SDGs are the most frequent: SDG 15 - life on land (n: 15), the SDG 7 - affordable and clean energy (n: 14), SDG 4 - quality education ( $n: 13)$, SDG 3 - good health and well-being ( $n: 12$ ), and SDG 8 - decent work and economic growth ( $\mathrm{n}: 12$ ). Like in polytechnics, the most frequent SDGs in the university courses are SDG 15 - life on land, and 7 - affordable and clean energy (n: 22 for each). In universities, other SDGs frequently addressed are SDG 6 - clean water and sanitation (n: 18), 
SDG 14 - life below water ( $n$ : 14), SDG 13 - climate action ( $n: 13)$, SDG 3 - good health and wellbeing ( $n: 13)$, and SDG 16 - peace, justice and strong institutions ( $n: 12)$.

Fisher's exact test performed to compare the number of courses addressing at least one SDG found no significant difference between polytechnics and universities ( $p$ value $=0.250$ ). However, significant differences were found between polytechnics and universities ( $p$ value $<0.05$ ) in SDGs 2 (zero hunger), 4 (quality education) and 8 (decent work and economic growth); these specific SDGs are addressed more often in polytechnic institutions. There is also a significant difference (p-value <0.05) in SDG 16 (peace, justice and strong institutions) where the universities' formative offer is greater.

With regard to the differences between undergraduate and master's degrees (Table 3), master's degrees have 158 courses addressing SDGs vis-à-vis 40 in undergraduate degrees. This is a statically significant difference (Fisher's exact test; $p$-value $=0.000$ ). At the undergraduate level, the most frequent SDGs are: the SDGs 7 - affordable and clean sanitation ( $n: 13)$ and 15 - life on land (n: 11); and at the master level, they are: SDG 15 - life on land ( $\mathrm{n}: 26)$, SDG 7-affordable and clean sanitation (n: 23) and SDG 3 - Good health and well-being (n: 22).

Significant differences are found between undergraduate and master degrees in six SDGs, with masters having more courses addressing the following ( $p$ value $<0.05$ in Fisher's Exact Test): SDG 3 (good health and well-being), SDG 4 (quality education), SDG 8 (decent work and economic growth), SDG 10 (reduce inequalities), SDG 12 (responsible consumption and production) and SDG 16 (peace, justice and strong institutions).

The study proceeded with the analysis of the scientific domains and scientific areas of the courses covering SDGs, using the FCT (Fundação para a Ciência e a Tecnologia; The Foundation for Science and Technology) list as a tool to divide the scientific areas. As can be seen from Table 4 , social sciences and humanities is the scientific domain with most courses involving SDGs ( $\mathrm{n}$ : 73; $36.9 \%$ ), directly followed by the natural and environmental sciences ( $\mathrm{n}: 71 ; 35.9 \%)$. The life and health sciences have the fewest courses ( $n: 19 ; 9.6 \%)$. Universities have more SDG related courses than Polytechnics in all scientific domains except life and health sciences.

Table 4 - Scientific areas of the degrees that include SDG topics, by type of institution and type of course

\begin{tabular}{ccccccccccc}
\hline \hline & \multicolumn{4}{c}{ Type of HEI } & \multicolumn{2}{c}{ Type of Course } & \multirow{2}{*}{ Total } \\
\cline { 2 - 9 } Scientific area & Polytechnic & University & $\begin{array}{c}\text { Undergraduate } \\
\text { Degree }\end{array}$ & Master & \\
\cline { 2 - 9 } & $\mathrm{N}$ & $\%$ & $\mathrm{~N}$ & $\%$ & $\mathrm{~N}$ & $\%$ & $\mathrm{~N}$ & $\%$ & $\mathrm{~N}$ & $\%$ \\
\hline $\begin{array}{c}\text { Exact Sciences and } \\
\text { Engineering }\end{array}$ & 14 & $7.1 \%$ & 21 & $10.6 \%$ & 13 & $6.6 \%$ & 22 & $11.1 \%$ & 35 & $17.7 \%$
\end{tabular}




\begin{tabular}{|c|c|c|c|c|c|c|c|c|c|c|}
\hline Life and Health Sciences & 11 & $5.6 \%$ & 8 & $4.0 \%$ & 3 & $1.5 \%$ & 16 & $8.1 \%$ & 19 & $9.6 \%$ \\
\hline $\begin{array}{c}\text { Natural and Environmental } \\
\text { Sciences }\end{array}$ & 29 & $14.6 \%$ & 42 & $21.2 \%$ & 21 & $10.6 \%$ & 50 & $25.3 \%$ & 71 & $35.9 \%$ \\
\hline $\begin{array}{c}\text { Social Sciences and the } \\
\text { Humanities }\end{array}$ & 27 & $13.6 \%$ & 46 & $23.2 \%$ & 3 & $1.5 \%$ & 70 & $35.4 \%$ & 73 & $36.9 \%$ \\
\hline Total & 81 & $40.9 \%$ & 117 & $59.1 \%$ & 40 & $20.2 \%$ & 158 & $79.8 \%$ & 198 & $100.0 \%$ \\
\hline
\end{tabular}

Note: The scientific domains follow the FCT criteria (FCT - Fundação para a Ciência e Tecnologia, 2017)

In all scientific domains, more master than undergraduate degrees have courses related to SDGs.

The natural and environmental sciences have most SDG related courses at the undergraduate level (n: 21; 10.6\%), and social sciences and humanities at the master level (n: 70; 35.4\%).

\section{Discussion}

The analysis of the public formative offer in Portugal shows that undergraduate and postgraduate degrees address the following SDGs most frequently: SDG 15 - life on land (examples of courses: bachelor Environmental Sciences, bachelor in Organic Farming, bachelor in Forestry and Natural Resources Engineering, bachelor and master in Environment Engineering, master in Forest Resources), and SDG 7 - affordable and clean energy (examples of courses: bachelor in Environmental Sciences, bachelor in Renewable Energy Engineering, master in Renewable Energy and Energy Efficiency, master in Sustainable Energies). Both highlight the current concerns about the environment for the future of humanity. The focus on these SGDs may reflect the increasing awareness of resource depletion and the need for both preservation of life and the development of sustainable solutions in the area of energy.

Governments nowadays are encouraging projects that adopt alternative energies and develop the circular economy through own financing (national and international funding) or good practices. There is also greater awareness about the issues related with life on land, notably land use, desertification and the development of organic and sustainable agriculture. According to Reed et al. (2016), land use planning is a mechanism to reduce poverty, conserve biodiversity, and preserve forests and natural resources. HEls adjust the formative offer in line with the needs of the labour market, and courses in the area of energy and life on land naturally emerge if there is demand from the market (i.e., governmental agencies, corporations, non-governmental companies and consumers).

The United Nations, governments and the media constantly remind society of the sustainability problems that will be faced in the near future. For example, the Horizon 2020 program strives to improve areas aligned to major policy priorities worldwide such as Building a low-carbon, climate resilient future and Connecting economic and environmental gains - the Circular 
Economy (European Commission, 2018). The program is built around three pillars, one of which is entitled Societal Challenges. The seven areas addressed in this pillar include: (i) the Societal Challenge 2 - Food Security, Sustainable Agriculture and Forestry, Marine, Maritime and Inland Water Research and the Bioeconomy, and (ii) Societal Challenge 5 - Climate Action, Environment, Resource Efficiency and Raw Materials. These two societal challenges are relevant to the courses studied at the two different levels of education. The European Commission states that the Societal Challenges identified in the Europe 2020 Strategy represent economic opportunities for businesses and contribute to competitiveness and employment in the Union (European Commission, 2018). Given that HEls create and offer courses that should respond to societal needs, this may explain why there are more courses in the areas of life on land and affordable and clean energy (vis-a-vis other SDG areas).

Following the 24th Conference of the Parties to the United Nations Framework Convention on Climate Change (COP24-COP 24 Katowice 2018), the results related to SDG 13 Climate Action are clearly relevant. The results showed 16 courses in the area, most of which were offered by universities (13 of the 14 universities have a course in the SDG13 area). Recent studies have revealed the need for this topic to be introduced in university curricula (Morgado et al., 2017), and our results show the topic was vertically introduced in the ESD in universities but scarcely addressed in polytechnics.

For most of the SDG, there are no significant differences in the way polytechnics and universities vertically integrate SDGs in courses. Although universities have a much more theoretical, research-oriented and academic focus than polytechnics in Portugal, the formative offer is becoming more similar in some courses (e.g., engineering, sociology) and this is reflected in the way HEls address SDGs. Nonetheless, polytechnics have devoted more attention to SDGs 2, 4 and 8 than universities, while universities give greater focus to SDG 16 than polytechnics. Most of the courses addressing SDG2 are related to agrarian sciences (example of courses addressing SDG2: bachelor and master in Organic Farming, master in Right to Food and Rural Development) which have a strong tradition in polytechnic education in Portugal due to their applied research and practical nature. Most courses on SDG 4 are in the area of education (examples: master in Social Education, Development and Local Dynamics, master in Adult Education and Training and Community Intervention, master in Environmental Education); in this case, the polytechnic system offers more courses related with environmental education whereas polytechnics and universities have a similar number of social education and special education courses. The SDG 8 courses are in the education, social innovation, tourism and management areas; polytechnic 
institutions offer more courses in these areas probably due to the applied research and practical nature of polytechnic education (examples: master in Entrepreneurship and Social Innovation, master in Sustainable Tourism Management, master in Education and Social Intervention). The courses addressing SDG 16 are in the areas of law, international studies and public policies which are taught in the university system in Portugal due to legal constraints (e.g., law courses are only offered by universities) and greater experience in knowledge creation and the development of conception, innovation and critical analysis skills in these areas (examples: master in Crime, Difference and Inequality, master in Human Rights, master in International Relations - Peace, Security and Development Studies).

The study reveals that master's degrees include more SDG-related courses. This is in part due to the higher specialization of master courses but also because they can adapt more easily to demand and to requirements from the market. The most striking differences are found in courses related with SDG 3, 4, 8, 10,12, and 16. This is due to the fact that master courses can offer specialized knowledge and research in response to immense global and local challenges, namely ensuring healthy lives and promoting wellbeing for all at all ages (SDG3), ensuring inclusive and equitable quality education and promoting lifelong learning opportunities for all (SDG4), decent work and economic growth (SDG4), reducing inequalities (SDG8), ensuring sustainable consumption and production patterns (SDG10) and promoting peaceful and inclusive societies for sustainable development, providing access to justice for all and building effective, accountable and inclusive institutions at all levels (SDG16).

Albareda-Tiana et al. (2018) state that implementing SDGs in HEls provide an opportunity, supported by public policies, to include ESD competences in teaching and to enable students to mobilize in response to problems.

Various scholars have noted that HEls can foster the transition to a sustainable society, namely by creating and transferring knowledge to the society and preparing students for their future in society (Wiek et al., 2016; Leicht, Heiss and Byun, 2018; Leal Filho et al. 2019, Findler, Schönherr, Lozano and Stacherl, 2019). To this end, it is essential that the ESD in HEls prepares graduates to make responsible decisions and develops competences that improve employability.

There are two SDG with fewer courses than expected: SDG1 and SDG5. SDG 1 - no poverty was not explicitly addressed in any degree program according to the analysis of the course designations and objectives. This is in line with the results obtained by Albareda-Tiana et al. (2018), for the International University of Catalonia, where there is no reference to SDG 1 in any 
degree program. On the other hand, this SDG is not considered a strategic priority in Portugal which comes within the group of countries with very high human development and its position in the UN Human Development Index has been rising since 1990 (United Nations Development Programme, 2018).

SDG5 - Gender equality - was explicitly addressed in only three master courses offered at different universities (example of course: master in Women's Studies). These courses address the role of women in society and culture and also women's rights. As expected, there are no courses associated to SDG 17 - Partnerships for the goals; this is explained by the time elapsed since the publication of SDGs and the specific nature of this SDG. In fact, this SDG needs a holistic intervention (e.g., partnerships between HEI, companies and government) that is probably better addressed through the institutions' political dimension than their educational offer.

The scientific areas with most SDG-related courses are social sciences and humanities and the natural and environmental sciences. This is also evidenced in the study by Fonseca et al. (2018) on course addressing sustainability offered by HEls. In contrast, life and health sciences have the fewest courses addressing SDG. For all scientific domains except life and health sciences, universities have more SDG related courses than Polytechnics. More master courses address SDGs than undergraduate degrees in all scientific domains-

Relatively to the SDGs that were prioritized by the Portuguese government, the most courses are offered on SDG 4 and SDG 14 and the fewest on SDG 5. This draws attention to the need for Portuguese public entities to increase the formative offer in Portugal's strategic areas, notably in SDG5.

Although with an average of 6 courses per HEl aligned with the SDG, only $7.7 \%$ of courses addressed at least one SDG. This modest result may be due to the lack of national integrated strategies or policies, plans or programs on the integration of ESD into Portuguese HEls (Farinha et al., 2017).

\section{Conclusion}

This study provides a critical analysis of the inclusion of SDG in Portuguese HEls. HEIs' integration of ESD varies considerably and some institutions are already addressing more of the SDGs to develop a culture for SD. The results show that in Portugal: (a) 198 courses directly and explicitly address at least one SDG; (b) on average, each HEI has 6 courses that explicitly address at least one SDG; (c) universities have more courses in SDG areas than polytechnics; (d) more master's 
degrees embrace the SDGs than undergraduate degrees; (e) most of the courses addressing SDGs are from the social sciences and humanities areas and from natural and environmental sciences; (f) the SDGs addressed by the most undergraduate and master courses are SDG 15 life on land, and SDG 7 - affordable and clean energy.

Despite the small number of courses directly and explicitly addressing SDGs, this may be because Portuguese HEls have not yet had time to respond to the United Nations publication of the SDGs in 2015. This paper provides a first analysis and inventory of the vertical integration of SDGs in the Portuguese higher education system. This should be followed in future studies by an indepth analysis and detailed study of curricular unit syllabuses, teaching methodologies and research conducted by professors and students.

The main practical implications of this study are twofold. First, the small number of courses embracing SDGs - notably those considered a strategic priority by Portuguese Government three years after the publication of the SDGs (United Nations, 2015) highlights the importance of developing public policies that motivate Portuguese HEls to create and offer courses on these topics. Second, this paper serves to raise the awareness of Portuguese higher education institutions of their role and responsibility in furthering SDG. HEls could address the SDGs more explicitly in each course. The SDG could be operationalized in several ways (course objectives, development of competencies, teaching methodologies, research by professors and students) and HE's contribution to the SDGs and target would be clearer if HEls explicitly mention each course's link with SDG (if any).

Sustainability is a new political agenda, but it is also crucial for all institutions to fulfil their responsibility to promote proactive dynamics between institutions, agents and individuals. Albareda-Tiana et al. (2018) propose several guidelines/suggestions for the successful inclusion of SGD in curricula that would be appropriate in Portuguese HEls; more specifically: (i) introduce ESD and the SDGs into degree curricula; (ii) the curricula must be consistent with the HEIs' mission; and (iii) a holistic methodological strategy for integration into the labour market that combines theory and practice. The paper provides a reflection on SDG implementation in HEls and highlights the urgency of reforming curricula for a sustainability society. The 2030 development agenda and the SDGs are a framework for collaboration by HEls in curriculum and their other activities in pursuit of SD.

The study has two main limitations. First, in practice, ESD is not only achieved in HEl through undergraduate and master courses. Although doctorate programs, specializations and 
postgraduate courses are now being offered that can pursue SDG, these were not considered in the analysis. Second, the content of curricular units and the teaching methodologies of HEls were not analyzed herein. This study examined the vertical integration of ESD in HEls through the analysis of SDGs associated to courses and the course designations and objectives. An analysis of the curricular unit's syllabus and methodologies could identify more courses related with the SDGs. It would therefore be fruitful in future research to analyze the study plans and syllabuses of courses at different levels of education as well as the link between the integration of SD competences and the inclusion of SGDs within HEI curricula.

\section{References}

Albareda-Tiana, Vidal-Raméntol \& Fernández-Morilla, (2018). "Implementing the sustainable development goals at University level", International Journal of Sustainability in Higher Education, 19, 473-497.

Aleixo, A.M., Azeiteiro, U. \& Leal, S., (2018a). "The implementation of sustainability practices in Portuguese higher education institutions", International Journal of Sustainability in Higher Education, 19, 146-178.

Aleixo, A.M., Leal, S. \& Azeiteiro, U., (2018b). "Conceptualizations of sustainability in Portuguese higher education: roles, barriers and challenges toward sustainability", Journal of Cleaner Production, 172, 1664-1673.

Amaral, L.P., Martins, N. \& Gouveia, J.B., (2015). "Quest for a sustainable university: a review", International Journal of Sustainability in Higher Education, 16, 155-172.

Bardin, L., (2014). Análise de Conteúdo Edições 70: Coimbra.

Barth, M. \& Rieckmann, M., (2012). "Academic Staff Development as a Catalyst of Curriculum Change Towards Education for Sustainable Development: An Output Perspective ", Journal of Cleaner Production, 26, 28-36.

Brondani, S.C., Brandli, L.L., Frandoloso, M.a.L. \& Vieira, S., (2014). "Panorama da sustentabilidade ambiental nas melhores universidades da américa latina", Revista Aidis de Ingeniería y Ciências Ambientales: Investigación, desarollo y prática, 7, 1-10.

Elder, M., Bengtsson, M. \& Akenji, L., (2016). "An Optimistic Analysis of the Means of Implementation for Sustainable Development Goals: Thinking about Goals as Means", Sustainability 8.

Farinha, C., Azeiteiro, U.M. \& Caeiro, S., (2017). Education for Sustainable Development Through Policies and Strategies in the Public Portuguese Higher Education Institutions. In W. Leal Filho, U.M. Azeiteiro, F. Alves \& P. Molthan-Hill (eds.) Handbook of Theory and Practice 
of Sustainable Development in Higher Education: Volume 4. Springer International Publishing: Cham, 275-290.

Farinha, C.S., Azeiteiro, U. \& Caeiro, S.S., (2018). "Education for sustainable development in Portuguese universities: The key actors' opinions", International Journal of Sustainability in Higher Education, 19, 912-941.

Farinha, C.S., Caeiro, S. \& Azeiteiro, U., (2019). "Sustainability Strategies in Portuguese Higher Education Institutions: Commitments and Practices from Internal Insights," Sustainability, 11, 1-25.

Fct - Fundação Para a Ciência E Tecnologia, (2017). Domínios Científicos de Áreas Cientificas [online].

https://www.fct.pt/apoios/projectos/concursos/2012/docs/Dominios_e_Areas_Cientif icas_C2012.pdf [Accessed Access Date

Figueiró, P.S. \& Raufflet, E., (2015). "Sustainability in higher education: a systematic review with focus on management education", Journal of Cleaner Production, 106, 22 - 33.

Findler, F., Schönherr, N., Lozano, R., \& Stacherl, B. (2019). “Assessing the Impacts of Higher Education Institutions on Sustainable Development: An Analysis of Tools and Indicators", Sustainability, 11(59), 1-19. https://doi.org/10.3390/su11010059

Fonseca, L.M., Portela, A.R., Duarte, B., Queirós, J. \& Paiva, L., (2018). "Mapping higher education for sustainable development in Portugal", Management \& Marketing. Challenges for the Knowledge Society, 13, 1064-1075.

Hajer, M., Nilsson, M., Raworth, K., Bakker, P., Berkhout, F., Boer, Y.D., Johan Rockström, Ludwig, K. \& Kok, M., (2015). "Beyond Cockpit-ism: Four Insights to Enhance the Transformative Potential of the Sustainable Development Goals", Sustainability, 7, 1651-1660

Katiliūtè, E., Daunorienè, A. \& Katkutè, J., (2014). "Communicating the sustainability issues in higher education institutions World Wide Webs", Procedia - Social and Behavioral Sciences, 156, $106-110$.

Krippendorff, K., (2013). Content Analysis: an Introduction to its Methodology SAGE: London.

Leal Filho, W. (ed.) (2018) Implementing Sustainability in the Curriculum of Universities: Approaches, Methods and Projects, Springer: Hamburg.

Leal Filho, W., Azeiteiro, U., Alves, F., Pace, P., Mifsud, M., Brandli, L., Caeiro, S.S. \& Disterheft, A., (2017a). "Reinvigorating the sustainable development research agenda: the role of the sustainable development goals (SDG)", International Journal of Sustainable Development \& World Ecology.

Leal Filho, W., Brandli, L.L., Castro, P. \& Newman, J., (2017b). Handbook of Theory and Practice of Sustainable Development in Higher Education Springer International Publishing.

The original article is available at: https://doi.org/10.1108/IJSHE-04-2019-0150 
Leal Filho, W., Shiel, C., Paço, A., Mifsud, M., Ávila, L.V., Brandli, L.L., Molthan-Hill, P., Pace, P., Azeiteiro, U.M., Vargas, V.R. \& Caeiro, S., (2019). "Sustainable Development Goals and sustainability teaching at universities: Falling behind or getting ahead of the pack?", Journal of Cleaner Production, 32, 285-294.

Lei N. 46/86 - Lei De Bases Do Sistema Educativo [Law No. 46/86 - Basic Law of the Educational System], (Diário da República n.o 237/1986). Lei n. 46/86 - Lei de Bases do Sistema Educativo [Law No. 46/86 - Basic Law of the Educational System] [online]. https://dre.pt/application/conteudo/222418 [Accessed Access Date

Leicht, A., Heiss, J. \& Byun, W.J., (2018). Issues and trends in education for sustainable development

Lozano, R., (2010). "Diffusion of sustainable development in universities curricula: an empirical example from Cardiff University", Journal Clean Production, 18, 637-644.

Lozano, R., Ceulemans, K., Alonso-Almeida, M., Huisingh, D., Lozano, F.J., Waas, T., Lambrechts, W., Lukman, R. \& Hug, J., (2015). "A review of commitment and implementation of sustainable development in higher education: results from a worldwide survey", Journal of Cleaner Production, 108, 1-18.

Morgado, F., Bacelar-Nicolau, P., Osten, J.R.V., Santos, P., Leonor Bacelar-Nicolau, H.F., Alves, F., Soares, A.M.V.M. \& Azeiteiro, U.M., (2017). "Assessing university student perceptions and comprehension of climate change (Portugal, Mexico and Mozambique)", International Journal of Climate Change Strategies and Management, 9, 316-336.

Orsies - Observatório Da Responsabilidade Social E Instituições De Ensino Superior, (2018). Livro Verde Sobre Responsabilidade Social e Instituições de Ensino Superior [Green Paper on Social Responsibility and Institutions of Higher Education]. Forum Estudante, Portugal.

Popescu, M. \& Beleau, C., (2014). "Improving management of sustainable development in universities ", Bulletin of the Transilvania University of Braşov, 7, 97-106.

Radford, A., (2012). "A Critical Assessment of University Sustainable Development Policy: A Gloucestershire Case Study", Earth \& E-nvironment, 8, 210-241.

Ramos, T., Caeiro, S., Hoof, B.V., Lozano, R., Huisingh, D. \& Ceulemans, K., (2015). "Experiences from the implementation of sustainable development in higher education institutions: Environmental Management for Sustainable Universities", Journal of Cleaner Production, 106, 3-10.

Reed, J., Van Vianen, J., Deakin, E.L., Barlow, J. \& Sunderland, T., (2016). "Integrated landscape approaches to managing social and environmental issues in the tropics: learning from the past to guide the future", Global Change Biol. 
Segalàs, J., Ferrer-Balas, D. \& Mulder, K.F., (2010). "What do engineering students learn in sustainability courses? The effect of the pedagogical approach", Journal of Cleaner Production, 18, 275-284.

Sibbel, A., (2009). "Pathways towards sustainability through higher education", International Journal of Sustainability in Higher Education, 10, 68-82.

Stough, T., Ceulemans, K., Lambrechts, W. \& Cappuyns, V., (2017). "Assessing sustainability in higher education curricula: A critical reflection on validity issues", Journal of Cleaner Production, 1-11.

Thomas, I., (2016). Challenges for implementation of education for sustainable development in higher education institutions. In M.M. Barth, G./Thomas, I./Rieckmann, M. (ed.) Routledge Handbook of Higher Education for Sustainable Development. London, 56-71.

Unesco, (2014). Shaping the Future We Want: UN Decade of Education for Sustainable Development (2005-2014). United Nations Educational, Scientific and Cultural Organization.

United Nations, (2015). Transforming Our World: The 2030 Agenda for Sustainable Development (A/RES/70/1) [online]. https://undocs.org/A/RES/70/1 [Accessed Access Date 2018].

United Nations Development Programme, (2018). Human Development Indices and Indicators: 2018 Statistical Update.

Wals, A.E.J., (2014). "Sustainability in higher education in the context of the UN DESD: a review of learning and institutionalization processes", Journal of Cleaner Production, 62, 8 - 15.

Wiek, A., Bernstein, M., Foley, R., Cohen, M., Forrest, N., Kuzdas, C., . . Withycombe Keeler, L. . , (2015). Operationalising competencies in higher education for sustainable development Handbook of Higher Education for Sustainable Development. Routledge, London, 241-260.

Wiek, A., Withycombe, L. \& Redman, C.L., (2011). "Key Competencies in Sustainability: A Reference Framework for Academic Program Development", Sustainability Science, 6, 203-218.

\section{Short bio-note about authors}

Ana Marta Aleixo is currently working as a postdoctoral at Aveiro University. Her research is about the topic "The Commitment of the Portuguese's Higher Education Institutions to achieve Sustainable Development Goals". She also works at Polytechnic of Leiria in the Projects' Office. Her PhD was held at the Open University and the thesis was related with the "Sustainable Higher 
Education Institutions: Sustainable Development Challenges of Portuguese Education Institutions". Her research over the past 10 years has covered the topics of social responsibility and sustainable development in Portuguese higher education institutions.

Ulisses M Azeiteiro is a Senior Professor (Associate Professor with Aggregation / Habilitation and Tenure) and Coordinator of the Climate Change and Biodiversity Assets Unit from the Biology Department and Integrated Member/Senior Researcher of the Centre for Environmental and Marine Studies (CESAM) at University of Aveiro in Portugal. His main interests are climate change and sustainability / and Adaptation to Climate Change in the Context of Sustainable Development (Social and Environmental Sustainability and Climate Change). He has written, cowritten, edited or co-edited more than 250 publications, including books, book chapters, special Issues of scientific journals and papers in refereed journals.

Susana Leal is Assistant Professor in School of Management and Technology of Polytechnic Institute of Santarém, and a full member of the Life Quality Research Center, Portugal. She holds a PhD in Management from University of Coimbra, under the topic of Organizational Behavior and Corporate Social Responsibility, and a Master in Statistics and Information Management. She has a degree in Management. She conducts research activities on Sustainability, Corporate Social Responsibility, Ethics, Leadership, Organizational Commitment, Psychological Capital, Individual Performance, Quality of Life at Work, and on Social Economy topics. 